\title{
Senile macular changes in the black African
}

\author{
Z. GREGOR AND L. JOFFE \\ From Moorfields Eye Hospital and the Institute of Ophthalmology, London, and the \\ Department of Ophthalmology, University of Witwatersrand, South Africa
}

SUMMARY One thousand black African and 380 white Caucasian patients over the age of 50 were examined for evidence of age-related macular changes, namely, drusen, pigment epithelial atrophy, and disciform macular degeneration. Drusen and pigment epithelial changes were found to occur twice as commonly in Caucasians as in Africans; there was a much greater difference in the prevalence of disciform macular degeneration between the 2 groups. The cause of the differences remains unexplained.

Senile macular degeneration is a common cause of visual loss in Caucasians over the age of 50. With the rise of average age of population it has now become the leading cause of legal blindness in England and Wales (Sorsby, 1966). However, the disease is said not to be so common in other racial groups (Mann, 1966). It has been reported as rare in Negroes seen in the North American ophthalmic centres (Chisholm, 1975) and uncommon in the Mongolian races, despite a high incidence in the Chinese of central serous retinopathy (Lim, 1975). In South Africa macular degeneration has been observed in Negro patients but has been thought to be less common than in Caucasians, and disciform degeneration most unusual (Luntz, 1975). In an analysis of 144 diagnoses of Bantu (South African black) patients of all ages Mann found only 1 case of macular degeneration, though the total number of patients she examined is not stated.

The Bureau for the Prevention of Blindness organises 'eye camps' and carries out surveys of eye disease in many parts of South Africa. In an analysis of 58310 diagnoses established in 41 surveys between 1947 and 1953 macular degeneration was found in 6 patients $(0.01 \%)$. The total number of patients examined and their ages were not stated. In 1960 in an analysis of causes of registered blindness in the Bantu macular degeneration is not even mentioned; however, $51 \%$ of patients were found to be blind from 'unknown causes' and not all the notifications were done by ophthalmologists (Mann, 1966).

It is well recognised that those lesions giving rise

Address for reprints: Z. Gregor, FRCS, Moorfields Eye Hospital, City Road, London ECIV 2PD to visual loss in senile macular degeneration, namely, disciform degeneration and geographic atrophy of retinal pigment epithelium, are preceded by drusen and pigment epithelial change (Gifford and Gushman, 1940; Gass, 1973; Sarks, 1976; Gregor et al., 1977).

The aim of this study was to determine whether senile macular degeneration (and the changes which lead to it) occur in black patients. In order to do this we compared a sample of African (Bantu) patients with an age and sex matched sample of Caucasian (British) patients.

\section{Patients}

One thousand consecutive black African patients over the age of 50 years presenting at the outpatient clinic at St. John's Eye Hospital in Johannesburg (706 patients) and at the Umlamli Mission Hospital, Transkei (294 patients), were examined for evidence of macular disease; all patients of mixed race were excluded from the study. Similarly, 380 consecutive Caucasian patients were examined in the casualty department of Moorfields Eye Hospital, London.

All the patients over the age of 50 were examined, regardless of the nature of their initial presentation. They were entered into the study consecutively every day throughout the duration of the study ( $6 \frac{1}{2}$ weeks at Baragwanath, 10 days in Transkei, and $5 \frac{1}{2}$ weeks at Moorfields).

\section{Methods}

The patient's name, age, race (or tribe in the Africans), relevant history, and details of examination were recorded on a standard form. The patient's 
pupils were fully dilated, and the macular region was assessed by direct and indirect binocular ophthalmoscopy and, in most cases, by slit-lamp biomicroscopy. Where necessary the fundus abnormalities were investigated by fundus photography and fluorescein angiography. Zeiss (Oberkochen) fluorescein cameras were used.

The purpose and nature of the examination was explained to the patients and was carried out only with their consent.

The number of patients with senile macular changes in each group was compared by the chisquare test.

\section{Results}

One thousand black African and 380 white Caucasian patients over the age of 50 were examined for evidence of senile macular degeneration. Of the African patients $136(13.6 \%)$ were excluded from the study because it was impossible to examine the macular area adequately owing to bilateral lens opacities (117 patients), bilateral corneal opacities (9 patients), gross diabetic maculopathy (6 patients), and bilateral rhegmatogenous detachment (4 patients). Only 3 patients were excluded from the Caucasian group owing to bilateral lens opacities.

In 233 African patients $(23.3 \%)$ only 1 macula could be examined adequately because of unilateral lens opacity (181 patients), corneal opacity (44 patients), vitreous haemorrhage (8 patients), and rhegmatogenous detachment (1 patient).

In the Moorfields group $11(2.9 \%)$ patients had the following uniocular conditions which prevented adequate examination of the macula: 5 had retinal detachment, 4 had unilateral cataract, and 2 had vitreous haemorrhage.

Of the 630 African patients in whom both maculae could be examined, 7 had senile changes in 1 eye only and the other eye appeared normal; the same was true of 2 out of 377 Caucasian patients. In view of these low figures patients in whom only 1 macula could be examined were entered into the study as though both eyes were involved in the same process, so that the findings in 864 African and 377 Caucasian patients in whom at least 1 macula could be satisfactorily examined were used for comparison.

Age. Patients' ages ranged from 50 to a reputed 111 , though there were doubts about the credibility of some ages stated. The average age was 63.9 years in the African patients and 62.4 in the Caucasian group.

Sex. There were 503 males and 497 females in the African group and 191 males and 189 females in the Caucasian group.

Race. Both at Baragwanath and in Transkei the commonest 2 tribes were Xhosa $(33 \cdot 3 \%)$ and Sotho $(27.2 \%)$. The remainder were represented by Tswana (13.9\%), Zulu (12.6\%), Swazi (3\%), and Pedi ( $2.3 \%)$, and the remainder $(7.7 \%)$ was made up of 10 lessrepresented tribes. Most of the Moorfields patients were British, only 4 originating from other Western and Middle European countries.

Macular chang s. Senile changes were observed in $17.4 \%(150 / 864)$ African patients compared with $36.3 \%(137 / 377)$ Caucasian patients; this difference is significant $(\mathrm{P}<0.001)$. The remainder showed no signs of senile macular degeneration (714 African patients and 240 Caucasian patients) (Table 1).

The following categories of senile changes were compared: drusen, pigment epithelial changes, drusen associated with pigment epithelial change, geographic pigment epithelial atrophy, and disciform degeneration.

Drusen without any appreciable pigment epithelial change occurred in $9.3 \%$ (80) of African patients and in $18.3 \%(69)$ of Caucasian patients. Compared with the number of patients without senile changes, the difference between the 2 groups is significant $(P<0.001)$ (Table 2).

In the patients with macular drusen fine drusen were seen in $46.5 \%$ of Africans and $52 \%$ of Caucasians, large discrete solitary drusen in $50 \%$ of Africans and $45 \%$ of Caucasians, and confluent drusen in $3.5 \%$ of Africans and $2.9 \%$ of Caucasians (Table 3). There is no significant difference between the 2 groups.

Pigment epithelial changes were recognised in

Table 1 Incidence of senile macular changes

$\left.\begin{array}{lll}\hline & \begin{array}{l}\text { African } \\ \text { patients }\end{array} & \begin{array}{l}\text { Caucasian } \\ \text { patients }\end{array} \\ \hline \text { Total no. of cases } & 864 & 377 \\ \text { No. affected } & 150 & 137 \\ \text { Percentage of total } & 17.4 \% & 36.3 \%\end{array}\right\} \mathrm{P}<0.001$

Table 2 Type of senile macular changes

\begin{tabular}{llllll}
\hline & $\begin{array}{l}\text { African } \\
\text { Total } \\
\text { no. }\end{array}$ & $\begin{array}{l}\text { Percent- } \\
\text { age }\end{array}$ & $\begin{array}{l}\text { Caucasian } \\
\text { Total } \\
\text { no. }\end{array}$ & $\begin{array}{l}\text { Percent- } \\
\text { age }\end{array}$ & P value \\
\cline { 2 - 6 } & 80 & 9.3 & 69 & 18.3 & $<0.001$ \\
\hline $\begin{array}{l}\text { Drusen alone } \\
\begin{array}{l}\text { Pigment epithelial } \\
\text { changes alone }\end{array}\end{array}$ & 40 & 4.6 & 43 & 11.4 & $<0.001$ \\
$\begin{array}{l}\text { Combined drusen } \\
\text { and pigment } \\
\text { epithelial changes }\end{array}$ & 22 & 2.6 & 12 & 3.1 & $>0.1$ \\
$\begin{array}{c}\text { Disciform } \\
\text { degeneration }\end{array}$ & 1 & 0.1 & 13 & 3.5 & $<0.001$ \\
\hline
\end{tabular}


Table 3 Types of drusen

\begin{tabular}{lll}
\hline Type & $\begin{array}{l}\text { African } \\
(102 \text { cases }) \\
(\%)\end{array}$ & $\begin{array}{l}\text { Caucasian } \\
(81 \text { cases }) \\
(\%)\end{array}$ \\
\hline Fine drusen & 46.5 & 52 \\
Large discrete solitary & 50 & 45 \\
Confluent & 3.5 & 2.9 \\
\hline
\end{tabular}

$4.6 \%$ (40) of African patients and in $11.4 \%$ (43) of Caucasians $(\mathrm{P}<0.001)$ (Table 2).

Drusen and pigment epithelial change occurred together in $2.6 \%$ (22) of African patients and in $3.1 \%$ (12) of Caucasian patients. The difference is not significant $(\mathrm{P}>0 \cdot 1)$ (Table 2).

Geographic atrophy of pigment epithelium was observed in 4 African patients and in none of the Caucasian patients. These low figures could not be evaluated statistically.

Disciform degeneration was observed in only $0.1 \%$ (1) African patient, but among the Caucasian group in $3.5 \%(13)$ patients. This difference is statistically significant $(\mathrm{P}<0.001)$ (Table 2).

The $P$ value was also calculated for the difference in distribution of the senile macular changes, not taking into account the number of patients without senile change. The only significant difference was in the distribution of disciform degeneration $(P<0 \cdot 001)$. There was no statistical difference between the 2 groups for any of the other categories (drusen, pigment epithelial change, drusen combined with pigment epithelial change, and geographic atrophy). Similarly, there was no difference in distribution of the senile changes in any of the 4 age groups ( 50 to 59,60 to 69,70 to 79 , and 80 and over), apart from the disciform category, where the difference was significant $(\mathrm{P}<0.001)$.

\section{Discussion}

The results suggest that senile macular degeneration is less common in South African Bantu than in Caucasians and supports the observations of Luntz (1975) and Mann (1966) and the conclusions drawn from other surveys in South Africa (Mann, 1966).

At one time it seemed possible that the low frequency of senile macular changes in African populations was due to short life expectancy, but with increasing longevity it is now clear that this explanation is no longer adequate; it is more likely that the discrepancy is due to a 'racial factor independent of expectation of life' (Mann, 1966). If senile macular degeneration is genetically determined, as is believed by Gass (1973), then the 'racial factor' of Mann is heritable. It is unlikely to be the phenotypic expression of a gene limited to Caucasians, since the macular changes were seen in a large number of the black population studied.

Sampling error could also account for the differences recorded in this paper. In particular selective loss of visual acuity without loss of peripheral field may not be sufficient to induce illiterate patients to seek medical help. This survey was made on patients who came to hospital, and no account was taken of the patients' presenting symptoms. For this reason this criticism cannot be completely answered. However, the presence of drusen alone, which does not cause visual loss until advanced, was not the cause of the patients' attendance in either group. Sampling error does not appear to account for the differences between the 2 groups.

Despite the lower frequency of drusen and disciform lesions in the Bantu changes were identified in large enough numbers to allow comparison of the disease in the 2 groups. No comment is possible concerning geographic atrophy. Not only are drusen less common in the Bantu but the risk of drusen precipitating a disciform lesion also appears to be less. The genesis of a disciform lesion depends on the presence of subretinal neovascular tissue and the subsequent growth of this tissue. Any differences in the stimulus to neovascularisation or the behaviour of the new vessels in different racial groups would account for the higher prevalence of disciform degeneration in Caucasians. It has been shown that morphological differences of drusen can be related to the risk of developing disciform degeneration (Gregor et al., 1977), but the size and distribution of drusen between the 2 groups were identical.

This study indicates that senile macular degeneration occurs less commonly in African Bantu than in Caucasians, and that the evolution of the disease is also different in the 2 races. Such a finding awaits confirmation by a well-planned epidemiological study, and the differences remain unexplained.

We thank the Ophthalmological Section of the Royal Society of Medicine and the Keeler Foundation for their support. Our thanks also go to $\mathrm{Mr} \mathrm{H}$. Donovan, Computer Section of the Institute of Ophthalmology, the residents at St. John's and at Moorfields, the Bureau for the Prevention of Blindness for their co-operation. We should also like to thank $\mathrm{Mr} \mathrm{A}$. C. Bird for help with the manuscript, $\mathrm{Mr}$ A. M. Hamilton for his kindness and encouragement, and Miss Heather Lucas for secretarial assistance.

\section{References}

Chisholm, I. H. In preparation.

Gass, J. D. M. (1973). Drusen and disciform macular 
detachment and degeneration. Archives of Ophthalmology, 90, 206-217.

Gifford, S. R., and Cushman, B. (1940). Certain retinopathies due to changes in the lamina vitrea. Archives of Ophthalmology, 23, 60-75.

Gregor, Z., Bird, A. C., and Chisholm, I. H. (1977). Senile disciform degeneration in the second eye. British Journal of Ophthalmology, 61, 141-147.

Lim Siew Ming, A. (1975). Macular Workshop. Bath.

Luntz, M. H. (1975). Personal communication.
Mann, I. (1966). Culture, Race, Climate and Eye Disease, pp. 200-215, 239, 542. Charles C Thomas: Springfield, Illinois.

Sarks, S. A. (1976). Ageing and degeneration in the macular region: a clinico-pathological study. British Journal of Ophthalmology, 60, 324-341.

Sorsby, A. (1966). The incidence and causes of blindness in England and Wales 1948-1962. Ministry of Health, Report on Public Health and Medical Subjects No. 114. HMSO. 